ISSN: 2146-3042

DOI: 10.25095/mufad.607175

\title{
Muhasebe Sistemi Uygulama Genel Tebliği ile Finansal Raporlama Standartlarına Uygun Hesap Planı Taslağının Maliyet Hesapları Açısından Karşılaştırmalı Değerlendirilmesi ${ }^{*}$
}

\author{
Cevdet Yiğit ÖZBEK ${ }^{* *}$
}

\begin{abstract}
ÖZET Türkiye'de hali hazırda uygulanan muhasebe sisteminde tekdüzenin uygulanmasını sağlayan düzenleme 1992 yllının sonunda yasalaşmış, 1994 yılında ise uygulamaya girmiştir. Ekonominin giderek karmaşılklaşması Türkiye'de ve dünyada muhasebenin sürekli olarak gelişmesini ve değişmesini de gündeme getirmiştir. Yeni koşullara uygun muhasebe standartları geliştirilmiş, bunun sonucunda hesap planlarının güncellenmesi ihtiyacı da doğmuştur. Hesap planlarının standartlaştırılması; muhasebe ögretimi, muhasebe uygulamalarının elektronik ortamda yürütülmesi, muhasebe çalışanlarının iş değişikliğinde yeni işletmeye uyumu ve denetim gibi farkl yönlerden yarar sağlar. İhtiyaca uygun olarak oluşturulan Finansal Raporlama Standartlarına Uygun Hesap Planı Taslağı, Kaтu Gözetimi Muhasebe ve Denetim Standartları Kurumu tarafindan web sayfasında yayımlanarak görüş ve önerilere açılmıştır. Bu çalışma söz konusu Taslak'ta yer alan maliyet hesaplarının Muhasebe Sistemi Uygulama Genel Tebliği'nde yer alan maliyet hesapları ile karşılaştırılarak analiz edilmesine dayanmaktadır. Çalışmada nitel araştırma yöntemi kullanılmıştır. Analiz; hesap grupları, hesaplar ve hesap açıklamaları esas alınarak yapılmıştır. Çalışma sonucunda bazı hesap gruplarında önemli farklılıklar olduğu gözlemlenmiştir. Farklılık olan gruplarda hesap sayılarında artış olmuştur. Taslağın maliyet hesapları bazında mevcut hesap planına göre daha fazla hesap içerdiği, hesap açıklamalarının genel olarak daha ayrıntılı olduğu sonuçlarına ulaşılmıştır.

Anahtar Kelimeler: Muhasebe Sistemi Uygulama Genel Tebliği, Finansal Raporlama Standartlarına Uygun Hesap Plani, Maliyet Hesapları, Nitel Araştırma

Jel Sinıflandirması: M40, M41
\end{abstract}

Comparative Evaluation of General Communique on Accounting System Application andDraft Chart of Accounts in AccordanceWith Financial ReportingStandardsFromThe Point Of Cost Accounts

ABSTRACT

The regulation which is currently being applied in Turkey and which enabled implementation of uniformity in the accounting system, has become law in the end of 1992 and put into force in 1994. The fact that the economy has become more complex lead to accounting in Turkey and in the world to continuously develop and change. Accounting standards that are in compliance with new conditions were brought, and as a result of this, a need has arisen to update the chart of accounts. Standardization of chart of accounts provides benefits from various aspects such as carrying out accounting education and accounting applications in the electronic media, adaptation of accounting employees to new enterprise in case of change of job and auditing. The Draft Chart of Accounts In Accordance With Financial Reporting Standards, which was prepared in line with the needs, was published and opened for opinions and recommendations by Public Oversight Accounting and Audit Standards Authority. This study relies on comparison of cost accounts in the Draft in question with the costaccounts in the General Communique on Accounting System Application andits analysis. Qualitative research method was used in the study. The analysis was made based on the account groups, accounts and account explanations. It was observed that there were significant differences in some account groups as a result of the study. There has been an increase in the number of accounts in groups that were different. It was concluded that the draft included more accounts compared to the existing chart of accounts on the basis of cost accounts, and that the account explanations were more detailed in general.

Keywords: General Communique on Accounting System Application, Draft Chart of Accounts in Accordance with Financial Reporting Standards, Cost Accounts, Qualitative Research

Jel Classification: M40, M41

Makale Gönderim Tarihi: 01.06.2019

Makale Kabul Tarihi: 01.08.2019

Makale Türü: Kuramsal (Teorik) makale

${ }^{*}$ This paper is presented at the V. International Symposium on Accounting and Finance(ISAF 2019), 1-4 May 2019, Bursa, Turkey.

${ }^{* *}$ Associate Prof.., Ankara Hacı Bayram Veli Üniversitesi Bankacılık ve Sigortacılık Yüksekokulu, yigit.ozbek@ hbv.edu.tr ORCID: 0000-0002-5554-8124 


\section{GíRiș}

Türkiye'de muhasebe sisteminde tekdüzenin sağlanmasına yönelik ihtiyaç, uzun yıllar dile getirilmiştir. Ülke ekonomisinin lokomotifi olarak kabul edilen iktisadi devlet teşekküllerinde muhasebede tekdüzen çalışmaları özel sektörden yıllar önce başlatılmış ve Kamu İktisadi Teşebbüsleri için geliştirilen Tekdüzen Hesap Planı 1972 yılında yürürlüğe girmiştir. Kamuda rol alan iktisadi kurumlar muhasebe organizasyonlarını yaparken bu planı esas almıştır.

Özel sektör için tekdüzen hesap planı olarak kabul edilebilecek önemli düzenleme,1 Şubat 1984 tarihinde Sermaye Piyasası Kurulu (SPK) tarafından yayımlanan Seri VIII No: 7 tebliğ ile Standart Hesap Planı ve Planın Kullanım Esasları'dır (SPK, 1984). Amacı Sermaye Piyasası Kanunu'na tabi ortaklık ve aracı kurumların kullanacağı hesapların ve bu hesapların kullanımının tek düze hale getirilmesi anlamına gelen Standart Hesap Planı, özel sektöre ilişkin toplu halde uygulanan ilk tekdüzen hesap planı olarak kabul edilebilir. Daha sonra ekonomide önemli bir yer tutan bankaların yaptıkları işlemlerin tek tip muhasebeleştirilmesini sağlamak amacıyla 1.1.1986 tarihinde Tek Düzen Hesap Planı ve İzahnamesi uygulanmaya başlamıştır. Kamu sektörü, bankacılık sektörü ve Sermaye Piyasası Kanunu'na tabi ortaklık ve aracı kurumlar ekonomide önemli işlevleri olmasına karşın, toplam ekonominin önemli büyüklüğünü oluşturmaması nedeniyle tabana yaygın bir tekdüzen hesap planı ihtiyacı devam etmiştir.

1992 yılının sonunda bu arayışlara cevap verebilecek tekdüzen hesap planı Muhasebe Sistemi Uygulama Genel Tebliği (MSUGT) içerisinde yasalaşmış, 1994 yılında uygulamaya sokularak tekdüzen hesap planının daha çok işletmeyi kapsaması sağlanmıştır. Bankalar, sigorta şirketleri ve diğer finansal kurumlar dışındaki bilanço usulüne göre defter tutan işletmeleri kapsayan bu düzenleme ekonomi içinde faaliyet gösteren pek çok işletmeyi ilgilendirmektedir. Tebliğin düzenlenme amacı tebliğ hükümlerine tabi işletmelerin "faaliyet ve sonuçlarının sağlıklı ve güvenilebilir bir biçimde muhasebeleştirilmesi, mali tablolar aracılı̆̆ıyla ilgililere sunulan bilgilerin tutarlılık ve karşılaştırılabilirlik niteliklerini koruyarak gerçek durumu yansıtmasının sağlanması ve denetimin kolaylaştırılması" biçiminde ifade edilmiştir. Bu yapısıyla önemli faydalar sağlayan MSUGT, zaman içerisinde ölçme ve değerleme konularında uluslararası muhasebe standartlarına uyumlu düzenlemeler getirememiş olması, gerekli hesapları barındırmaması nedenleriyle de eleştirilmiştir (Akdoğan ve Sevilengül, 2007:31).Zaman zaman MSUGT'nde ihtiyaca uygun düzenlemeler yapılarak (enflasyon muhasebesi uygulaması gibi) güncel tutulmaya çalışılmıştır ve günümüzde de uygulaması sürmektedir. Daha çok vergi mevzuatı etkisinde kalmakla birlikte ulusal düzeyde muhasebe uygulamalarında tekdüzeliği sağlayan bu sistemin önemli bir parçası hesap planıdır.

Hesap planının standartlaştırılması; muhasebe öğretimi, muhasebe uygulamalarının elektronik ortamda yürütülmesi, muhasebe çalışanlarının iş değişikliğinde yeni işletmeye uyumu ve denetim gibi çeşitli açılardan önemlidir. 
Ekonominin her geçen gün karmaşıklaşması, ticarette yeni uygulamalar, yeni finansal araçlar doğal olarak muhasebeyi etkilemiş, Türkiye'de ve dünyada muhasebenin sürekli olarak gelişmesini ve değişmesini gündeme getirmiştir. Söz konusu gelişmeler bir süre sonra kullanılan muhasebe sisteminin yetersizliğini doğurmuştur. Yeni koşullara uygun uluslararası muhasebe standartları geliştirilmeye devam edilmiş, doğal olarak hesap planlarının güncellenmesi ihtiyacı doğmuştur. Türkiye de dünyadaki bu gelişmelere uzak kalamamış, uluslararası standartlarını uygulama fikri gelişmeye başlamıştır. Standartlara olan ilgi önceleri yalnızca akademik düzeyde sürdürülmüştür. 1994 yılında Türkiye Serbest Muhasebeci ve Mali Müşavirler ve Yeminli Mali Müşavirler Odaları Birliği (TÜRMOB) bünyesinde oluşturulan Türkiye Muhasebe ve Denetim Standartları Kurulu (TMUDESK) ile standartlaşma çalışmaları kurumsallaşmıştır. 1999 yılında bir kanuna eklenen madde ile Türkiye Muhasebe Standartları Kurulu (TMSK) kurularak muhasebe standardı çalışmalarıfarklı bir boyut kazanmıştır.

2005 yılından itibaren borsada işlem gören Sermaye Piyasası Kurulu (SPK) mevzuatına tabi şirketlerin, 2006 yılından itibaren bankaların, 2008 yılından itibaren sigorta şirketlerinin muhasebe standartlarını uygulaması zorunlu hale getirilmiştir. $\mathrm{Bu}$ şirketler ekonomi içerisinde önemi olan işletmeler olsa da standartların uygulanma kapsamı sınırlı kalmıştır.

2014 yılından itibaren Kamu Yararını İlgilendiren Kurumlara (KAYİK) da standartları uygulama zorunluluğu getirilerek kapsam genişletilmiştir. Bu arada2011 y1lında TMUDESK lağvedilerek yerine kurulan Kamu Gözetim Kurumu (KGK) tarafindan, Türkiye Muhasebe Standartları/Türkiye Finansal Raporlama Standartlarını uygulayan işletmeler için; finansal tablo örnekleri ve kullanım rehberi, bazı özel konuların muhasebeleştirilmesine yönelik ilke kararları ile TMS/TFRS'leri uygulamayan işletmelerin finansal tablolarına ilişkin ilave hususlar yayımlanarak finansal tabloların gerçeğe uygun sunulabilmesi amacıyla uygulamaya yön verilmiştir. KGK tarafından yayımlanan ilave hususlar, yeni bir standart seti hazırlanıncaya kadar geçerli olacak geçici bir çözüm amacı taşımaktaydı (Gökçen, Ataman ve Çakıcı, 2016: 22). Ayrıca KAYİK niteliğinde olmayan, ancak bağımsız denetime tabi olan işletmelere özel bir standart, BOBİ FRS adıyla 29.07.2017 tarihli mükerrer Resmi Gazete'de yayımlanarak 1.1.2018 tarih ve sonrasında uygulanmaya başlamıştır. Bütün bu gelişmeler yaşanırken standartlara uygun bir hesap planı çalışmaları da sürdürülmüştür. Hesap planının gerekliliği konusunda olumsuzluk içeren, işletmelerin kullandığı hesap planından ziyade finansal bilgilerin sunumunun önemli olduğuna (Altıntaş, 2011: 169) dair görüşler de bulunmaktadır. Bu görüşlerin kaynağı TMS/TFRS'lerin, finansal tablolar için kesin bir format vermemesidir. Standartların ana fikri, farklı sektörlerde faaliyet gösteren işletmelerin kendilerine özgü yapısını dikkate alarak finansal tablolarını "Kavramsal Çerçeve" ve "TMS 1: Finansal Tabloların Sunuluşu" standardına uygun olarak uygun hazırlayabileceğidir. Ancak Türkiye'de yıllardır uygulana gelen tekdüzen hesap planı, sağladığı avantajlarla bir gelenek yaratmış; gerçeğe ve ihtiyaca uygun, karşılaştırılabilir, doğrulanabilir ve anlaşılabilir bir sunum yapabilmek için standartlarla uyumlu bir hesap planı hazırlama beklentisi doğurmuştur. Genel olarak değerlendirildiğinde, tekdüzen muhasebe konusundaki görüş farklılı̆̆1 Türkiye'ye ve günümüze özgü değildir, örneğin Amerika Birleşik Devletleri’nde 1932 y1lından beri sürmektedir (Koç, 1972: 978).

Tartışmalar sürerken bir kamu otoritesi olan KGK, uygulama birliğini sağlamak açısından Finansal Raporlama Standartlarına Uygun Hesap Planı Taslağı'nı,Kurum'un web 
sayfasında yayımlayarak görüş ve önerilere açılmıştır. Bu çalışma Taslak'ta yer alan maliyet hesaplarının MSUGT'nde yer alan maliyet hesapları ile karşılaştırılarak analiz edilmesine dayanmaktadir.

\section{LITERATÜR TARAMASI}

Literatürde yapılan taramalarda muhasebe standartlarının açıklanması ve anlaşılmasına yönelik pek çok çalışma olduğu görülmektedir. Bu çalışmalarda muhasebe kaydı yapılması gerekli olduğunda yazarlar genellikle MSUGT'ni kullanmış, ancak çoğu yazar mevcut hesap planı ile standartlarla uyumlu gerçeğe uygun raporlama yapılmasının güçlügünden söz etmiştir. Örneğin, Özkan ve Terzi (2012) marka değerinin ölçümü ve değerlendirmesi konusunda yaptıkları çalışmada, MSUGT'nde işletme ile ilgili her türlü maddi olmayan duran varlığın standartlara uygun şekilde raporlanamadığını, bu nedenle MSUGT'ne göre düzenlenen finansal tabloların işletmenin gerçeğe uygun değerini göstermekten uzak olduğu bulgusunu ortaya koymuşlardır. Bazı yazarlar ise standartlar dikkate alınarak gerçeğe uygun raporlama yapılabilmesi için yeni hesap grupları önermiştir. Akdoğan ve Sevilengül'ün (2007) çalışması bu nitelikteki yayınların öncüsü olarak kabul edilebilir. Yazarlar çalışmalarında standartlara uyum için tekdüzen hesap planında yapılması gereken değişiklikleri incelemiş, mevcut hesap planına yeni hesap grupları önerirken var olan hesap gruplarının bazılarına yeni hesaplar eklenmesi gerektiğini vurgulamışlardır.

KGK tarafından 2018 yılı sonunda yayımlanan, Akdoğan ve Sevilengül'ün (2007) çalışmasının izlerini taşıdığı izlenimi veren Taslak'ın çok yeni olması nedeniyle konuyla doğrudan ilgili çalışmaya rastlanmamıştır. Ancak dolaylı olarak da olsa hesap planlarına atıfta bulunan bazı çalışmalar bulunmaktadır. Bu çalışmaların yazarlarından birisi olan Bayrı (2010) çalışmasında finansal durum tablosunu Tekdüzen Muhasebe Sistemi ile TMS/TFRS'ler bağlamında karşılaştırmıştır. Hesap planı karşılaştırması amacı taşımayan bu çalışma, finansal durum tablosunu biçimsel yapı, kapsam ve içerik yönleriyle karşılaştırarak değerlendirmiştir.

Doğrudan hesap planlarını ele almamasına karşın konuya yakın sayılabilecek çalışma Doğan (2018) tarafindan yapılmıştır. Yazar, çalışmasında BOBİ FRS ile Vergi Usul Kanunu (VUK) ve MSUGT'ni karşılaştırmış ve aralarındaki farklılık ve benzerlikleri ortaya koymuştur. Çalışmanın sonucunda, VUK ve MSUGT'nin bazı kalemlerin değerlemesi konusuna hiç yer vermediğini; kıdem tazminatı, amortisman ve reeskont gibi bazı uygulamaları ihtiyari bırakması gibi nedenlerle finansal tabloların gerçeğe uygun biçimde sunulmasının olası olmadığı; buna karşılık BOBİ FRS'ye göre düzenlenen finansal tabloların gerçeğe uygun sunuma olanak sağladığı tespiti yapılmıştır.

Dinç ve Atabay (2019) yaptıkları çalışmada var olan sistemdeki eksikliklerin TMS/TFRS ve BOBİ FRS uygulandıkça gözle görülür hale geldiğini belirtmişlerdir. Yazarlar tekdüzen muhasebe sisteminde gerçekliği bozan hükümleri; temel kavramlar, değerleme ölçüleri, mali tabloların sunumu, içeriklerinin incelenmesi ve hesap planı açılarından inceledikleri çalışmalarında, hesap planındaki özün önceliğine aykırı uygulamaların ortadan kaldırılabilmesi için yeniden düzenlenmesi gerektiğini vurgulamışlardır.

\section{YÖNTEM}

Taslak ve bu Taslak'ın bir bölümü olan maliyet hesaplarındaki yenilikler, hem 
uygulamacıların hem de akademisyenlerin ilgi alanına giren bir konudur. Çalışmanın araştırma sorusu Taslak'ta yer alan maliyet hesaplarının MSUGT'de yer alan maliyet hesapları ile karşılaştırılarak uygulamaya getirilen yenilikler olup olmadığı, varsa neler olduğudur. Analiz nitel araştırma yöntemi ile sonuçlandırılmaya uygundur. $\mathrm{Bu}$ nedenle çalışmada, nitel araştırma yöntemlerinden birisi olan, doküman inceleme (belgesel gözlem) yoluyla veri toplama tekniği kullanılmıştır. Doküman inceleme, sosyal olguların izleri olarak kabul edilen kayıt ve belgelerin sistemli bir biçimde incelenmesiyle verilerin toplandığ ve analiz edildiği tekniktir (Duverger, 1973: 96).Bu teknikte araştırmanın problem cümlesini oluşturan olguları içeren kaynaklar analize tabi tutularak yorumlanır. Araştırmamızda birer yazılı kaynak olan MSUGT ve Taslak incelenmiş, konuyla ilgili literatür taraması yapılmıştır. Yapılan incelemelere dayanarak düzenlemeler arasındaki farkl1lık ve benzerlikler ortaya konulmuş, farklı1ıkların yaratacağı sonuçlar tartışılmıştır.

\section{BULGULAR}

Analizden elde edilen bulgular sunulmadan önce araştırmanın içeriğini yönlendiren varsayımlar açıklanacaktır. Daha sonra bulgular; hesap sınıfı bazında genel değerlendirme, hesap grupları bazında değerlendirme ve hesap isimleri bazında değerlendirme olarak sinıflandırılarak sunulacaktır.

\subsection{Varsayımlar}

Hesap grupları bazında analiz yapılmadan önce bir varsayımda bulunma zorunluluğu doğmuştur. Çünkü Taslak’ta bazı hesap gruplarının hesap planı listesindeki ismi ile hesap planı açıklamaları kısmındaki ismi arasında uyumsuzluk vardır. Örneğin 7/A seçeneğinin tanıtıldığı (KGK, 2018: 161) sayfada;

$\checkmark \quad$ “70 Maliyet Bağlantı Hesapları ya da Maliyet Oluşum Hesapları” grubu açıklamalar kısmında "70 Maliyet Muhasebesi Bağlantı Hesapları ya da Maliyet Oluşum Hesapları” (KGK, 2018: 162),

$\checkmark \quad$ "74 Hizmet Üretim Giderleri” grubu açıklamalar kısmında "74 Hizmet Üretim Maliyetleri” (KGK, 2018: 173),

$\checkmark \quad$ "75 Araştırma ve Geliştirme Giderleri” grubu açıklamalar kısmında "75

Araştırma, Geliştirme ve Maden Kaynaklarının Aranması ve Değerlendirilmesi Giderleri" (KGK, 2018: 175),

$\checkmark \quad$ "77 Yönetim ve Genel İşletme Giderleri” grubu açıklamalar kısmında “77 Genel Yönetim Giderleri” (KGK, 2018: 178)

biçiminde isimlendirilmiştir. $\mathrm{Bu}$ farklılıkların sonradan düzeltilecek yazım hataları olduğu kanaatiyle doğru ifadelerin açıklamalar kısmında yer alan;

\footnotetext{
“70 Maliyet Muhasebesi Bağlantı Hesapları ya da Maliyet Oluşum

Hesapları"

"74 Hizmet Üretim Maliyetleri"

"75 Araştırma, Geliştirme ve Maden Kaynaklarının Aranması ve Değerlendirilmesi Giderleri"

$\checkmark \quad$ "77 Genel Yönetim Giderleri”
} 
başlıkları olduğu varsayılmıştır.

\subsection{Hesap Sınıfı Hakkında Genel Değerlendirme}

MSUGT'nde ve Taslak'ta hesapların sınıflandırılmasında aynı kod ve başlığı (7 Maliyet Hesapları) alan maliyet hesapları üzerinde yürütülen karşılaştırmalı araştırma sonucunda ilk bulgu olarak, maliyet muhasebesi uygulamalarında 7/A ve 7/B seçenekleri olarak bilinen ikili ayrımın korunarak devam ettirildiği; 7/A seçeneğinde büyük defter hesaplarının oluşturulmasında fonksiyon esasının, 7/B seçeneğinde büyük defter hesaplarının oluşturulmasında çeşit esasının benimsenmeye devam edildiği görülmüştür. Ayrıca 7 grubu hesapların dönem sonunda kalan vermemesi de iki hesap planı arasındaki ortak noktalardan birisidir. Hesap gruplarının isimlendirilmesi konusunda tek bir farklılık dikkat çekmektedir: "75 Araştırma ve Geliştirme Giderleri” grubunun ismi Taslak’ta "75 Araştırma, Geliştirme ve Maden Kaynaklarının Aranması ve Değerlendirilmesi Giderleri” biçiminde değiştirilerek gurubun işlevi genişletilmiştir. Diğer taraftan 70 grubunun başlığı Taslak'ta da aynı kalmakla beraber bu gruba farklı bir fonksiyon daha yüklendiği için grup iki başlığa sahip olmuştur.

\subsection{Hesap Gruplarının İsmi Bazında Değerlendirme}

Hesap gruplarının isimleri açısından bakıldığında büyük oranda benzerlik görülmesine karşın, Tablo 1'de görüldüğü gibi iki hesap grubunun isminde değişiklik bulunmaktadır. MSUGT'nde“70 Maliyet Muhasebesi Bağlantı Hesapları" iken Taslak'ta bu isim, eski isim korunarak genişletilmiş ve "70 Maliyet Muhasebesi Bağlantı Hesapları ya da Maliyet Oluşum Hesapları" olarak değiştirilmiştir. "75 Araştırma Geliştirme giderleri” grubunun ismi de genişletilerek "75 Araştırma, Geliştirme ve Maden Kaynaklarının Aranması ve Değerlendirilmesi Giderleri" biçiminde ifade edilmiştir. 70 grubundaki değişiklik muhasebe uygulamalarına getirilen bir yenilikten, 75 grubundaki değişiklik de kapsamın genişletilmesi ve standartların gerekliliğinden doğmuştur.

Tablo 1.Hesap Grubu İsimlerinde Değiş̧iklikler

\begin{tabular}{|l|l|}
\hline \multicolumn{1}{|c|}{ MSUGT } & \multicolumn{1}{c|}{ TASLAK } \\
\hline 70 MALIYYET MUHASEBESİ & 70 (700-701) MALIYYT MUHASEBESİ \\
BAĞLANTI HESAPLARI & BAĞLANTI HESAPLARI \\
& 70 (700-709) MALIYET OLUŞUM \\
& HESAPLARI \\
\hline 75 ARAŞTIRMA & 75 ARAŞTIRMA, GELIŞTİRME VE \\
GELİ̧̦TIRME GİDERLERİ & MADEN KAYNAKLARININ ARANMASI \\
& VE DEĞERLENDİRİMESİ GİDERLERİ \\
\hline
\end{tabular}

\subsection{Hesap İsimleri Bazında Değerlendirme}

Hesap isimleri esas alınarak yapılan karşılaştırmalı analizde karşımıza iki sonuç çıkmaktadır. Bunlardan biri Tablo 2'de gösterilen hesap isimleri bazında değişiklik göstermeyen gruplardır. Diğer sonuç ise Tablo 3'de gösterilen hesap bazında değişiklik gösteren gruplardır. 
Tablo 2. Hesap İsimleri Bazında Değişiklik Göstermeyen Gruplar

\begin{tabular}{|l|}
\hline \multicolumn{1}{|c|}{ GRUP İSIMLERİ } \\
\hline 71 DİREKT İLK MADDE VE MALZEME GIDDERLERİ \\
\hline 72 DİREKT İŞÇİIIK GİDERLERİ \\
\hline 74 HİZMET ÜRETIMM MALIYYETLERİ \\
\hline 76 PAZARLAMA SATIŞ VE DAĞITIM GİDERLERİ \\
\hline 77 GENEL YÖNETİM GİDERLERİ \\
\hline 78 FİNANSMAN GİDERLERİ \\
\hline 79 GİDER ÇEŞİTLERİ \\
\hline
\end{tabular}

Hesap ismi bazında değişiklik göstermeyen gruplardaki hesapların açıklaması ve işleyişi konularındaki farklılıklar çalışmanın ilerleyen başlıklarında vurgulanmıştır.

Tablo 3. Hesap İsimleri Bazında Değişiklik Gösteren Gruplar

\begin{tabular}{|l|l|}
\hline \multicolumn{1}{|c|}{ MSUGT } & \multicolumn{1}{c|}{ TASLAK } \\
\hline $\begin{array}{l}\text { 70 MALIYET MUHASEBESİ } \\
\text { BAĞLANTI HESAPLARI }\end{array}$ & $\begin{array}{l}70(700-701) \text { MALIYET MUHASEBESİ } \\
\text { BAĞLANTI HESAPLARI } \\
70(700-709) \text { MALIYET OLUŞUM HESAPLARI }\end{array}$ \\
\hline $\begin{array}{l}\text { 73 GENEL ÜRETIM } \\
\text { GIDERLERİ }\end{array}$ & 73 GENEL ÜRETİM GIDERLERİ \\
\hline $\begin{array}{l}\text { 75 ARAŞTIRMA } \\
\text { GELISSTİRME GİDERLERİ }\end{array}$ & $\begin{array}{l}\text { 75 ARAŞTIRMA, GELIŞTİRME VE MADEN } \\
\text { KAYNAKLARININ ARANMASI VE } \\
\text { DEĞERLENDİRILMESİ GIDERLERİ }\end{array}$ \\
\hline
\end{tabular}

İsmi aynı kalmakla birlikte Tablo 3'de MSUGT sütununda gösterilen "70 Maliyet Muhasebesi Bağlantı Hesapları" grubu Taslak'ta aynı isimle iki farklı grup olarak bölümlenmiştir. Bunlar: "70 (700-701) Maliyet Muhasebesi Bağlantı Hesapları" ve "70 (700709) Maliyet Oluşum Hesapları"dır. Bu grubun açıklamasında isteyen işletmelerin yalnızca 700 ve 701 hesaplardan oluşan "70 Maliyet Muhasebesi Bağlantı Hesapları"nı kullanabileceği belirtilmiştir. Grup bu haliyle MSUGT'den farklılık göstermemektedir. Ancak yine istemeleri halinde "70 Maliyet Oluşum Hesapları"nı kullanacak işletmeler için tümüyle yeni hesaplar söz konusudur.

\subsubsection{Maliyet Oluşum Hesapları Grubunun Değerlendirilmesi}

Tamamen yeni hesapları ve uygulamayı içeren Maliyet Oluşum Hesapları grubunu kullanmak isteyen işletmeler bir yandan fonksiyon hesaplarını kullanırken aktarmaları 70 grubunda tanımlanan ilgili hesaplara yapacaktır. "70 Maliyet Oluşum Hesapları" grubunu kullanmak isteyen işletmeler bu gruptaki hesapları farklı faaliyetlere ait maliyet oluşumları için kullanabilirler. Taslakta örnek olarak verilen hesaplar (bu hesapların örnek olarak verildiği, aynen kullanılmasının zorunlu olmadığı, işletmelerin hesapları ihtiyaçlarına göre düzenleyebilecekleri belirtilmiştir) esas alındığında bu faaliyetler; 


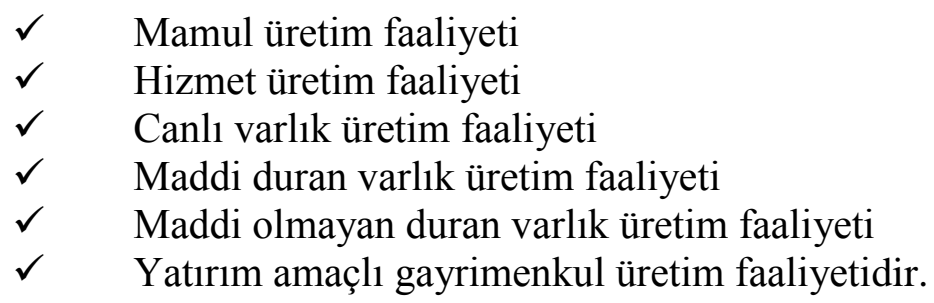

Mamul üretim faaliyetinde bulunan işletmeler MSUGT'ne uygun muhasebeleştirmede yarı mamul maliyetlerini bir bilanço hesabı olan "151 Yarı Mamuller Üretim" hesabında muhasebeleştirirken Taslağa göre işletmeler aynı uygulamayı "151 Yarı Mamuller" hesabında yürütebilirler. Yeni sunulan seçenekte dönem içinde henüz tamamlanmayan mamullerin (yarı mamuller) maliyeti Şekil 1'de gösterildiği gibi, "703 Üretim (İmalat)" hesabında da izlenebilir. Mamul tamamlandığında tamamlananların maliyeti doğrudan "152 Mamuller" hesabına alınır. Bu yöntemi seçen işletmeler için "151 Yarı Mamuller” hesabı yalnızca dönem sonunda "703 Üretim (İmalat)" hesabın aktarılması amacıyla kullanılır.

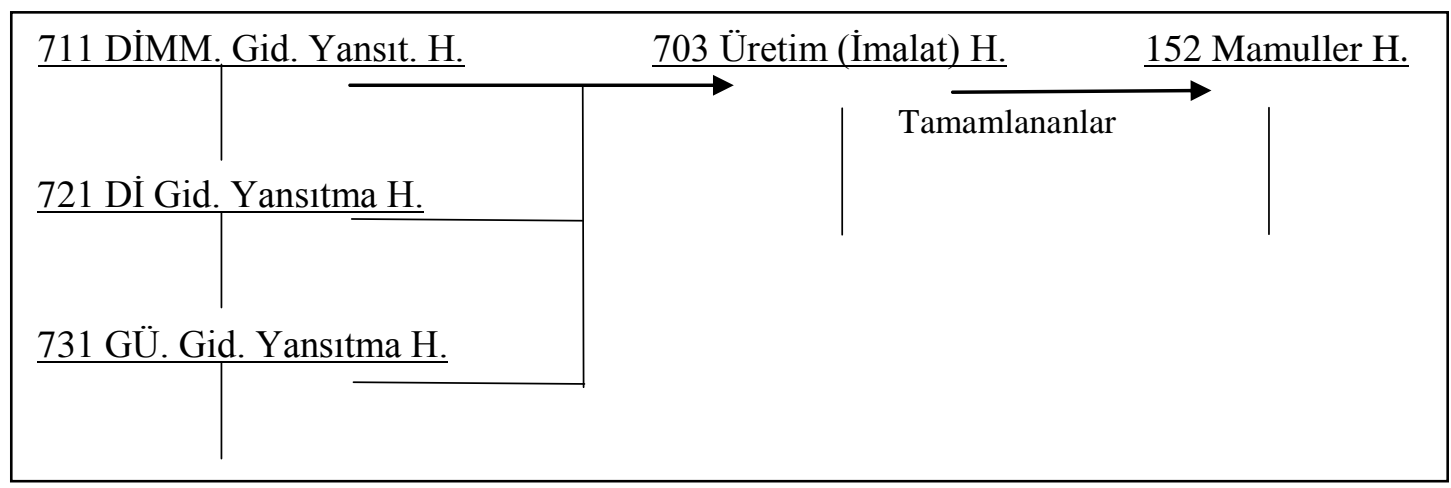

Şekil 1: 703 Üretim (İmalat) Hesabının Dönem İçi Kullanımı

Dönem sonlarında maliyet hesapları kapatılmak zorunda olduğundan "703 Üretim (İmalat)" hesabının borcunda bulunan tamamlanmamış mamullere ait tutarlar Şekil 2'de gösterildiği gibi bilançoda "151 Yarı Mamuller" hesabına aktarılırken, üretime ilişkin anormal fire ve kayıp tutarları fiili maliyet yöntemini uygulayan işletmelerde yeni bir kâr zarar tablosu hesabi olan "625 Stok Anormal Fire ve Kayipları" hesabina, "TMS 2: Stoklar"ve "BOBİ FRS Bölüm 6: Stoklar" standartları gereğince normal maliyet yöntemini kullanan işletmelerde dağıtıma tabi tutulamayan sabit genel üretim giderleri yine yeni bir kâr veya zarar tablosu hesabı olan "624 Dağıtılmayan Sabit Genel Üretim Giderleri" hesabına aktarılır (KGK, 2018: 19).“TMS 2: Stoklar” ve "BOBİ FRS Bölüm 6: Stoklar” standartlarında "sabit genel üretim maliyetlerinin dönüştürme maliyetlerine dağıtımı, üretim faaliyetlerinin normal kapasitede olacağı varsayımına dayanır" ifadesi normal maliyetlemeyi işaret etmektedir. "TMS 2: Stoklar" standardına göre üretim maliyetlerine dağıtılmayan genel üretim giderleri, "gerçekleştiği dönemde gider kaydedilerek sonuç hesaplarına alınır"; "BOBİ FRS Bölüm 6: Stoklar" standardına göre ise "gerçekleştiği dönemde "Satışların Maliyeti" kaleminde gösterilir” (KGK, TFRS 2019 Seti; KGK, BOBİ FRS). Muhasebeleştirildiği grup tartışmalı (Gökçen ve Öztürk, 2017: 110) olsa da Taslak’ta maliyetlere yüklenmeyen kısmın standartlara uygun olarak "62 Satışların Maliyetleri” grubunda muhasebeleştirilmesi öngörülmüş̧ür. 


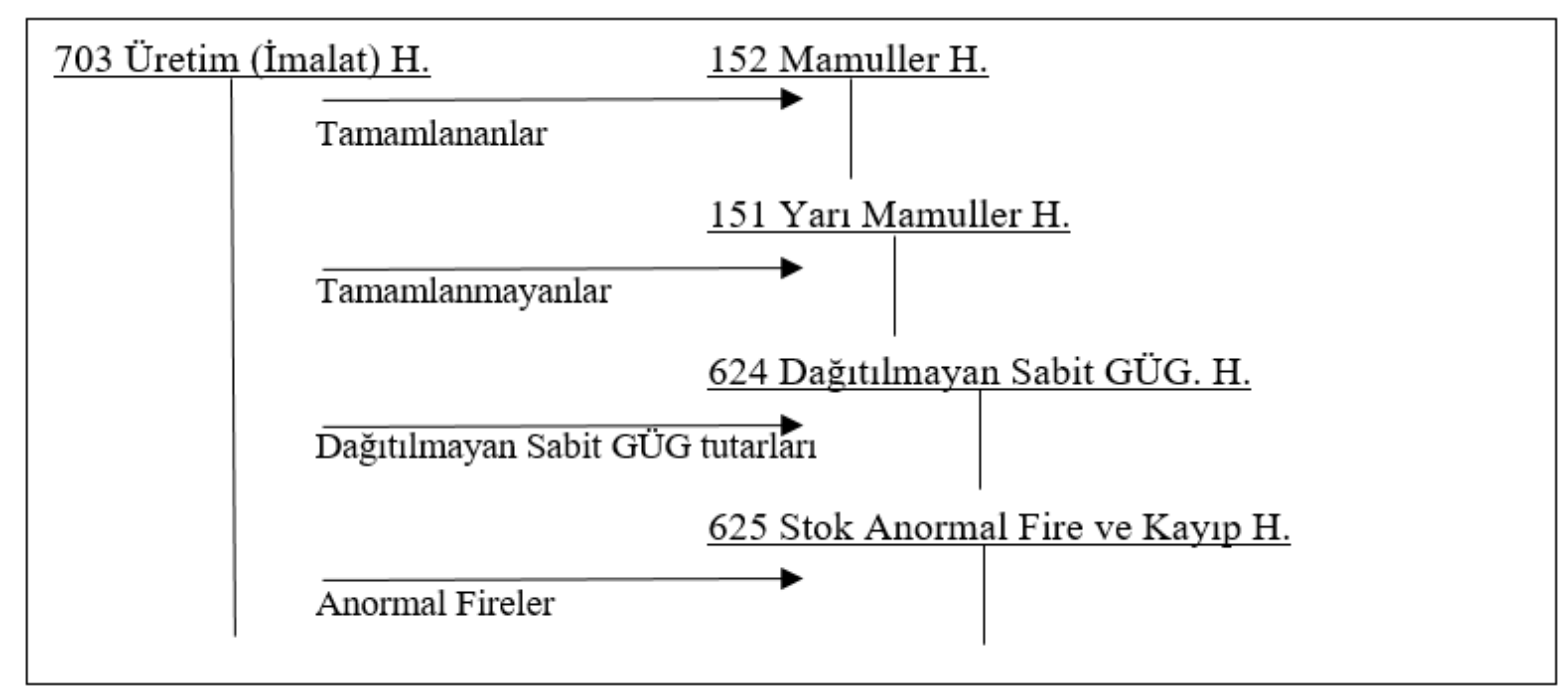

Şekil 2: 703 Üretim (imalat) Hesabının dönem sonu kullanımı

Hizmet üretim faaliyeti yapan işletmeler için TMS/TFRS'ler önemli yenilikler getirmiştir. Buna göre tamamlanmamış ve/veya henüz satılmamış hizmetler stoklarda gösterilebilir. MSUGT'ne uygun muhasebeleştirmede hizmetin stoklanması varsayımı bulunmadığı için, hesap planı hizmet maliyetinin stok hesaplarında izlenmesine uygun değildir. MSUGT uygulamasında hizmet maliyetleri oluştuğunda bir kâr zarar tablosu hesabı olan "622 Satılan Hizmet Maliyeti” hesabında muhasebeleştirir. Bu muhasebeleştirilme tarzında hizmetlerin üretildiği anda tüketildiği varsayılmaktadır. Taslakta hizmet işletmeleri için önemli farklı uygulamalar getirilmiştir. Bunlardan birisi hizmet üretimi ile ilgili maliyetlerin fonksiyon esasına göre de kaydedilebilmesidir. Buna göre hizmet işletmeleri üretim maliyet unsurlarını MSUGT’ndeki gibi gider çeşitlerine göre "740 Hizmet Üretim Maliyeti" hesabına kaydedebilirken, isterlerse bunları fonksiyon esasına göre "710 Direkt İlk Madde ve Malzeme Giderleri”, "720 Direkt İşçilik Giderleri” ve "730 Genel Üretim Gideri” hesaplarında da muhasebeleştirebilirler.

Diğer bir yenilik, hizmet üretim işletmeleri isterlerse MSUGT'nde yürüttükleri uygulamayı "622 Sunulan Hizmet Maliyeti” hesabında yürütebilirken, yeni sunulan seçenekte dönem içinde; tamamlanan ancak henüz satılmamış hizmet maliyetleri ile henüz tamamlanmayan hizmet maliyetlerini Şekil 3'de gösterildiği gibi, "705 Hizmet Üretim" hesabinda izleyebilirler. 


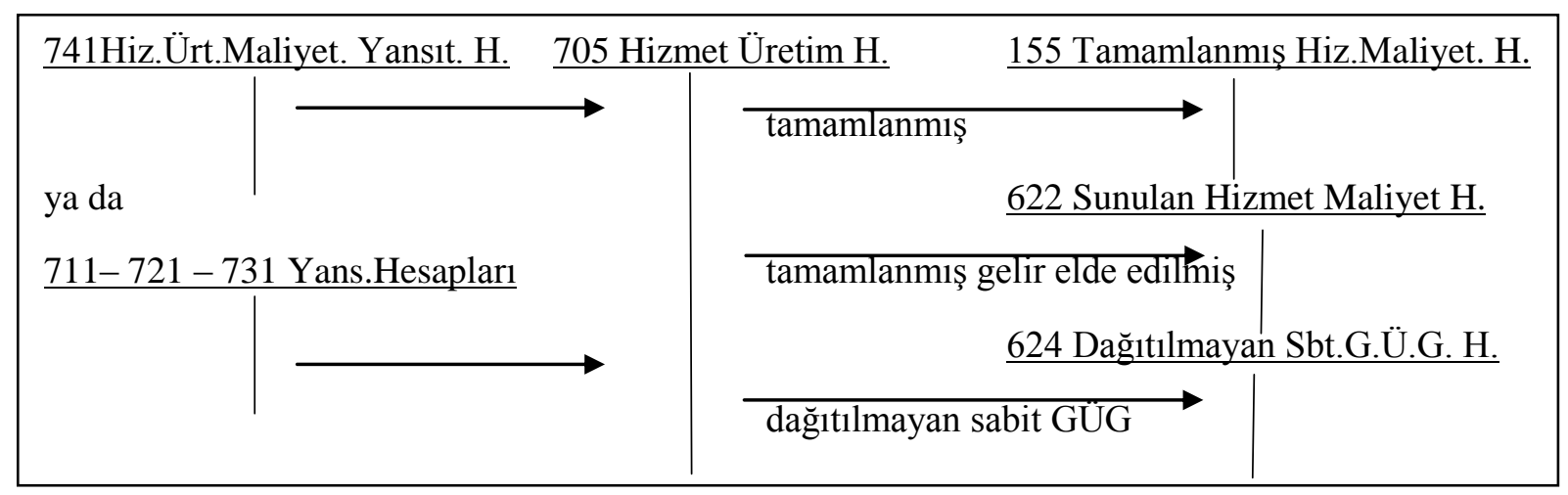

Şekil 3: 705 Hizmet Üretim Hesabının Dönem İçi Kullanımı

Dönem içinde hizmet tamamlandığında satış yapılana kadar hizmetin maliyeti, doğrudan "155 Tamamlanmış Hizmet Maliyetleri" hesabına alınır. Tamamlanıp gelir elde edilen hizmet maliyeti "705 Hizmet Üretim" hesabı alacaklandırılarak "622 Sunulan Hizmet Maliyeti” hesabına aktarılır. Dönem içerisinde henüz tamamlanmamış hizmet maliyetlerinin aktarılmasına gerek duyulmaz, "705 Hizmet Üretim" hesabında bırakılır. Raporlama tarihinde maliyet hesapları kapatılacağından "705 Hizmet Üretim” hesabı Şekil 4'deki gibi alacaklandırılarak tamamlanıp henüz gelir elde edilmeyen hizmet maliyetleri "155 Tamamlanmış Hizmet Maliyetleri" hesabına, tamamlanıp gelir elde edilen hizmet maliyetleri "622 Sunulan Hizmet Maliyetleri" hesabına, tamamlanmayan hizmet maliyetleri "154 Tamamlanmamış Hizmet Maliyetleri" hesabına ve dağıtılmayan genel üretim giderleri "624 Dağıtılmayan Genel Üretim Giderleri” hesabına aktarılır. Böylece dönem sonunda "705 Hizmet Üretim" hesabı kapatılarak ilgili olduğu bilanço ve kar zarar tablosu hesaplarına dağıtılmış olur.

2018 y1lı öncesi TMS/TFRS setlerinde "TMS 2: Stoklar" standardında "verilen hizmetle ilgili hasılatın mali tablolara gelir olarak yansıtılmadığı durumlarda ilgili giderler stok hesabına yansıtılır" ifadesi bulunmaktaydı. Tamamlanmış / Tamamlanmamış Hizmet Maliyetleri hesapları ile hayat bulan bu ifade 2018 ve sonrası TMS/TFRS setlerinde "TMS 2: Stoklar" standardından kaldırılmış, "TFRS 15: Müşteri Sözleşmelerinden Hasılat" standardına atıfta bulunulmuştur. "TMS 2: Stoklar", "TMS 16: Maddi Duran Varlıklar" veya "TMS 38: Maddi Olmayan Duran Varlıklar" gibi standartların kapsamına girmeyen bir sözleşmeyle ilişkili olarak katlanılan maliyetler, "TFRS 15: Müşteri Sözleşmelerinden Hasılat" standardının "Sözleşmeyi Yerine Getirme Maliyetleri” başlıklı paragraftaki şartların tamamının karşılanması koşuluyla, finansal durum tablosuna varlık olarak alınabilirler (KGK, TFRS 2019 Seti). Bununla birlikte "BOBİ FRS Bölüm 6: Stoklar" standardının "Hizmet Sağlayan İşletmelerin Stok Maliyeti” başlığında, 2018 öncesi TMS/TFRS setinde yer alan "TMS 2: Stoklar" standardıyla uyumlu olarak; hizmet işletmelerinin "eğer varsa stoklarını bunların üretimi için katlanılan maliyetler üzerinden ölçerler" ifadesi bulunmaktadır (KGK, BOBİ FRS). 


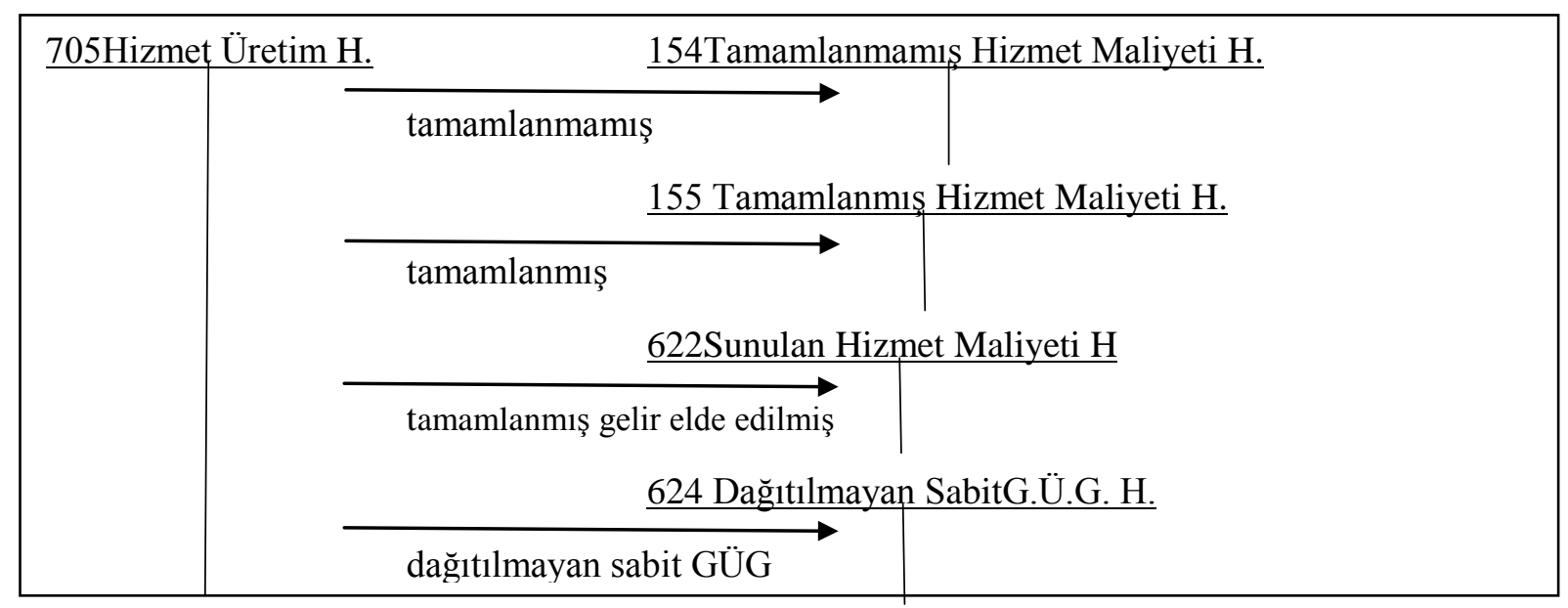

Şekil 4: 705 Hizmet Üretim Hesabının Dönem Sonu Kullanımı

Yıllara yaygın inşa (taahhüt) ve hizmet işi yapan işletmeler de "705 Hizmet Üretim" hesabını kullanabilirler. Bu tip işletmeler dönem içerisinde tamamlanan maliyetlerini gelir elde ettiklerinde "622 Sunulan Hizmet Maliyeti" hesabinın borcuna, tamamlanmayan kısımlarla ilgili maliyetleri ise "182 Önceden Yapılan İnşa Taahhüt ve Hizmet İşleri" hesabının borcuna aktararak "705 Hizmet Üretim" hesabını alacaklandırırlar."TFRS 15: Müşteri Sözleşmelerinden Hasılat" standardı veya "BOBİ FRS Bölüm 5: Hasılat"standardını uygulayan işletmeler, taahhütte bulundukları işlerle ilgili gelecekteki faaliyetlerine ilişkin katlandıkları maliyetlerini ve taahhüt ettikleri işin tamamlanmayan kısmıyla ilgili maliyetlerini182 kodlu hesapta izlerler (KGK, TFRS 2019 Seti; KGK, BOBİ FRS). Fiili maliyet yöntemini kullanan işletmelerde oluşan fire tutarları "625 Stok Anormal Fire ve Kayıplar" hesabının borcuna aktarılır. Yıllara yaygın inşa (taahhüt) ve hizmet işi yapan işletmelerde "705 Hizmet Üretim” hesabınının akışı Şekil 5'de gösterilmiştir.Yıllara yaygın inşaat faaliyetine ilişkin harcamalarını ve hakkedişlerini geçici kabule bağlı olarak kâr zarar hesaplarına aktaran işletmeler, yani tamamlanmış sözleşme yöntemini kullanan işletmeler, bu faaliyetlerinin maliyetlerini "16 Yıllara Yaygın İnşaat ve Onarım Maliyetleri" grubundaki 160-167 kodlu hesaplarda aktifleştirirler. Bu tip işletmeler TFRS veya BOBİ FRS'yi uygulamayan işletmelerdir.

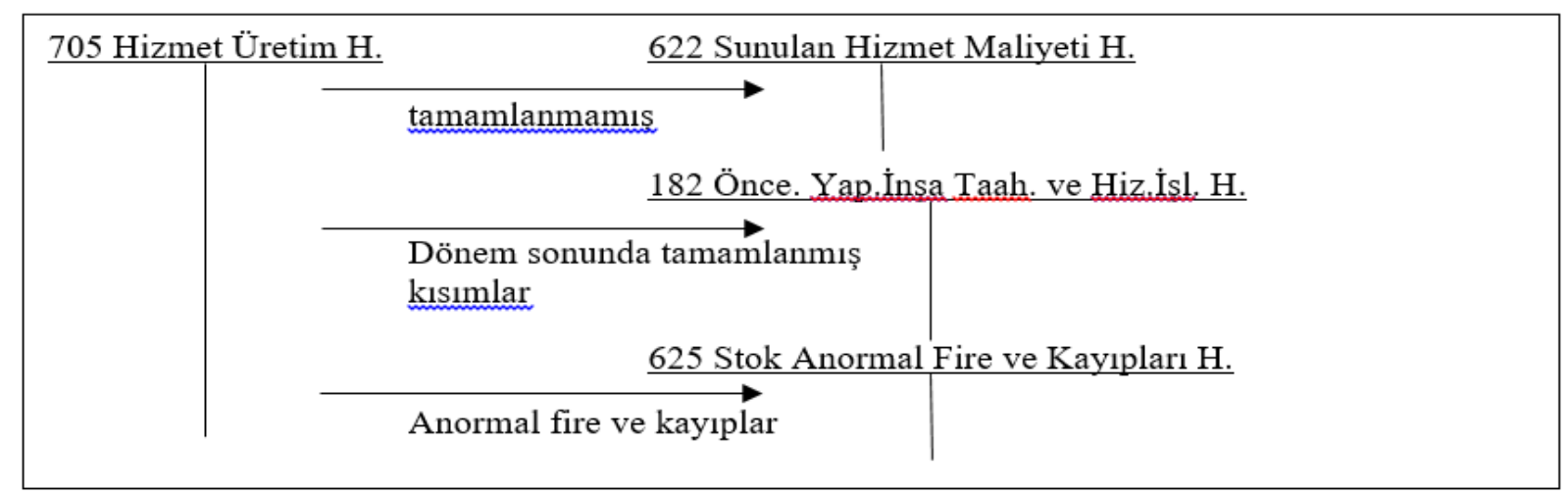

Şekil 5: 705 Hizmet Üretim Hesabının Yıllara Yaygın İnşa ve Hizmet İşinde Kullanımı 
MSUGT'nde“TMS 41 Tarımsal Faaliyet” standardı gereğince tarımsal faaliyette bulunan işletmelerin ürettikleri canlı varlıkların maliyetlerini muhasebeleştirmek amacıyla kullanılabilecek özel hesap / hesaplar bulunmamaktadır. Oysa canlı varlıklar, değişim kapasitesine sahip, değişimleri yönetilebilen ve ölçülebilen varlıklardır (Akdoğan ve Sevilengül, 2007: 45). Canlı varlıklar bu nitelikleri nedeniyle kendilerine özgü hesap grupları olmadan raporlandıklarında yapılan raporlamanın gerçeğe uygunluğu sınırlı kalmaktadır. Üstelik vergi mevzuatı nedeniyle standardın ölçme ve değerleme bölümlerine uygun bir muhasebeleştirme yapmak da olanaksız olduğundan bu işletmelerde gerçeğe uygun raporlama yapma olanağı ölçme açısından da sinırlanmaktadır (Özulucan ve Deran, 2008: 2122). Taslakta canlı varlıklar üreten işletmelere yeni sunulan seçenekte dönem içinde canlı varlıklar için yapılan direkt ilk madde ve malzeme, direkt işçilik ve genel üretim giderleri Şekil 6'da gösterildiği gibi, yansıtma hesapları aracılığıyla "702Canlı Varlıklar Üretim" hesabına aktarılabilecektir. Bu hesapta biriken maliyetler uygun tutarlarla 17/27 Canl1 Varlıklar gruplarındaki ilgili canlık varlık hesabına (Bahçe Bitkileri, Küçükbaş Hayvanlar v.b. gibi) aktarılır. Böylece canlı varlıklara ilişkin maliyet oluşumunun tamamı 70 grubu içinde izlenmiş olur. Ancak bu yöntemi seçen işletmeler, canlı varlık oluşumu henüz tamamlanmamış olsa bile dönem sonunda "702Canlı Varlıklar Üretim" hesabında biriken tutarları ilgili hesaplara aktarırlar. "702 Canlı Varlık Üretim" hesabını kullanmayı tercih etmeyen işletmeler canlı varlıklar için yapılan direkt ilk madde ve malzeme, direkt işçilik ve genel üretim giderleri tutarlarını dönem sonlarında söz konusu hesapların yansıtma hesapları aracılığıyla 17/27 Canlı Varlıklar gruplarındaki ilgili canlık varlık hesabına aktarırlar. Canlı varlıkların stoklara benzediği halde Stoklar grubundan farklı bir grupta muhasebeleştirilmesinin nedeni, elde tutuldukları sürece değişime uğrayabilmeleridir (Akdoğan ve Sevilengül, 2007: 45).

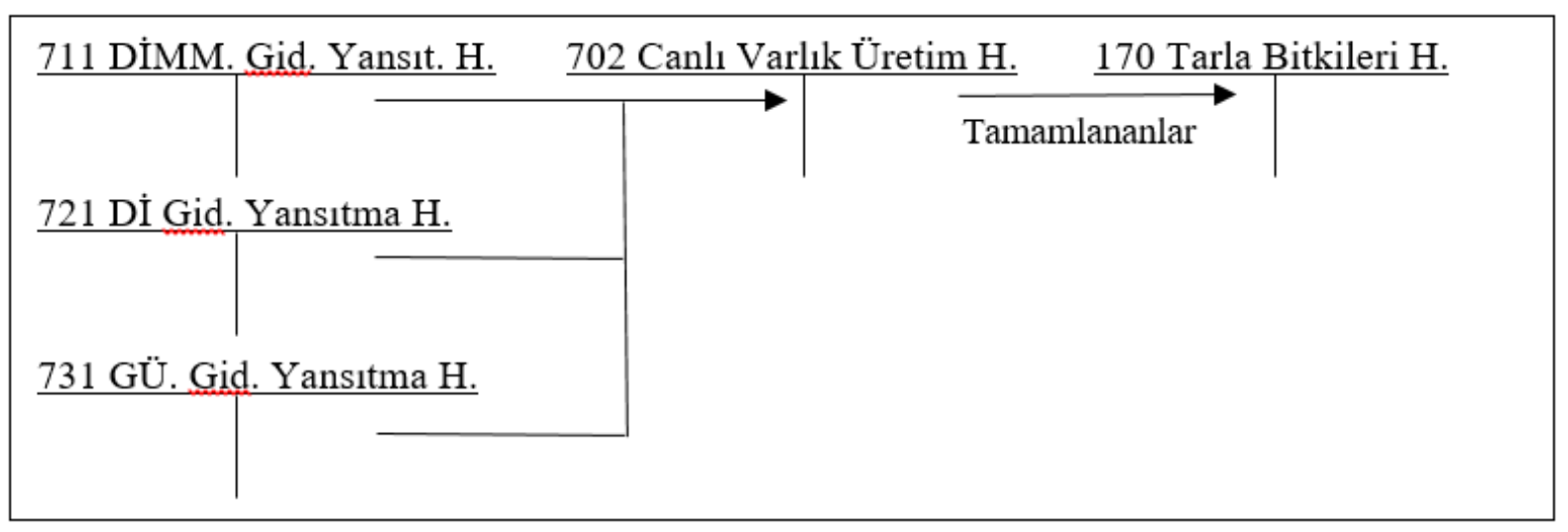

Şekil 6: 702 Canlı Varlık Üretim Hesabının Dönem İçi Kullanımı

Kullanacakları maddi duran varlıkları kendileri imal/inşa eden işletmeler MSUGT'ne uygun muhasebeleştirmede maliyet unsurlarını bir bilanço hesabı olan "258 Yapılmakta Olan Yatırımlar" hesabında izlerken Taslak'ta işletmelere aynı uygulamayı "259 Yapılmakta Olan Maddi Duran Varlık Yatırımları ve Verilen Avanslar" hesabında yürütme olanağı verilmektedir.Yeni sunulan seçenekte imali /inşası devam eden maddi duran varlıklara ilişkin maliyet unsurları Şekil 7'de gösterildiği gibi, “706Yapılmakta Olan Maddi Duran Varlık Yatırım Maliyetleri” hesabında da izlenebilir. Bu yöntemi seçen işletmeler için "259 Yapılmakta Olan Maddi Duran Varlık Yatırımları" hesabı, dönem sonunda henüz 
tamamlanmamış varlık maliyetlerinin "706 Yapılmakta Olan Maddi Duran Varlık Yatırım Maliyetleri” hesabından aktarılması amacıyla kullanılacaktır.

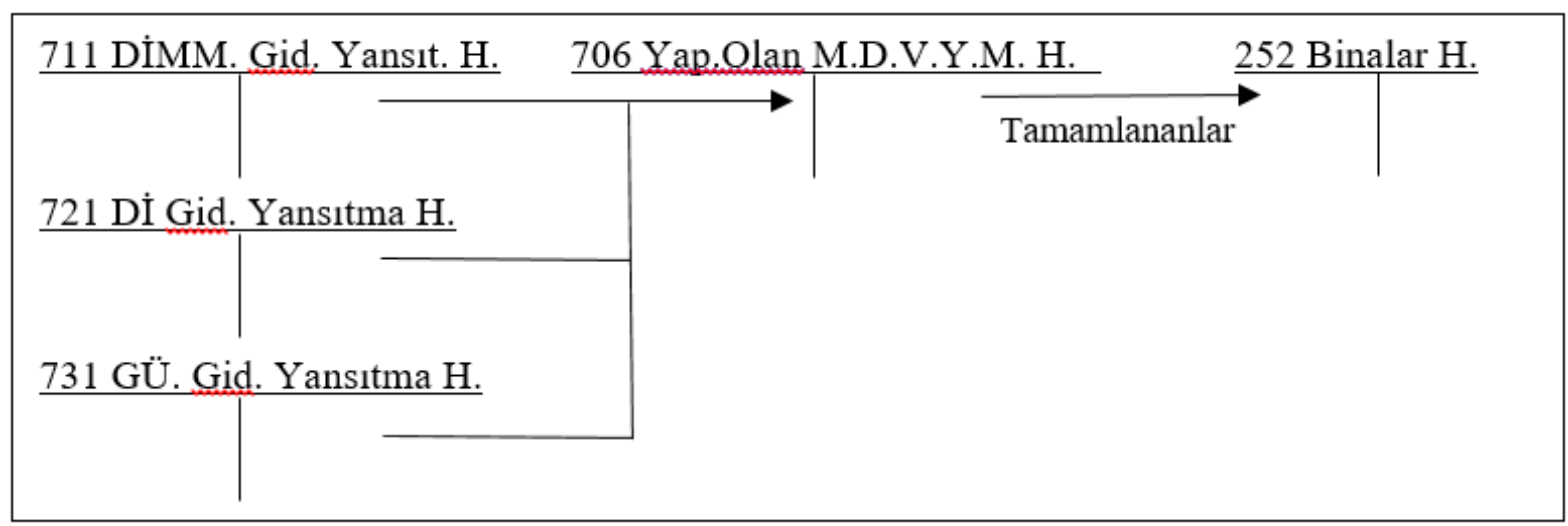

Şekil 7: 706 Yapılmakta Olan Maddi Duran Varlık Yatırım Maliyetleri Hesabının Dönem İçi Kullanımı

İşletme içerisinde oluşturulan maddi olmayan duran varlıklar için yapılan direkt ilk madde ve malzeme, direkt işçilik ve genel üretim giderleri "751 Araştırma Giderleri Yansitma" hesabı alacaklandırılarak "707 Yapılmakta Olan Maddi Olmayan Duran Varlık Yatırım Maliyetleri" hesabına aktarılır. "TMS 38: Maddi Olmayan Duran Varlıklar" ve "BOBİ FRS Bölüm 14: Maddi Olmayan Duran Varlıklar" standartlarında, maddi olmayan duran varlığın oluşumunda araştırma safhası ile geliştirme safhasından söz edilmiştir. "Bir maddi olmayan duran varlık yaratılmasına ilişkin işletme içi bir projenin araştırma safhasını geliştirme safhasından ayırt edememesi durumunda, söz konusu projeye ilişkin harcamalar sadece araştırma safhasında yapılmış gibi dikkate alınıp" gider olarak muhasebeleştirilmektedir (KGK, TFRS 2019 Seti; KGK, BOBİ FRS).Söz konusu standartların bu paragrafı dikkate alınarak dönem sonlarında 707 kodlu hesap alacaklandırılarak geliştirme aşamasındaki harcamalardan aktifleştirilmesi uygun olanlar "26 Şerefiye ve Maddi Olmayan Duran Varlıklar" grubundaki uygun hesaba aktarılırken, aktifleştirilmesi uygun olmayan tutarlar da Şekil 8'de gösterildiği gibi "630 Araştırma ve Geliştirme Giderleri” hesabına aktarılarak gider kaydedilir.

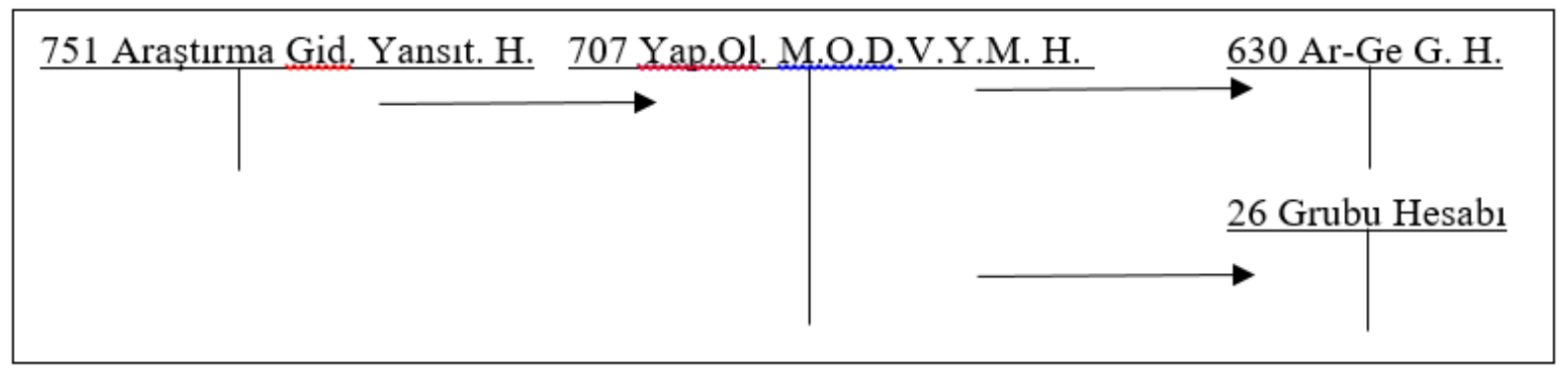

Şekil 8: 707 Yapılmakta Olan Maddi Olmayan Duran Varlık Yatırım Maliyetleri Hesabının Dönem İçi Kullanımı

MSUGT'ne uygun muhasebeleştirmede maddi duran varlıkların; kullanma,kiralama veya değer artışından yararlanma gibi farklı amaçlarla edinilmesinde farklı muhasebe 
uygulaması bulunmamaktadır. Bu nedenle yatırım amaçlı gayrimenkul kavramına uygun bir gayrimenkulün işletme tarafından inşası durumunda maddi duran varlıkların inşasından farklı bir uygulama yapılmamaktadır. Ancak "TMS40: Yatırım Amaçlı Gayrimenkuller” ile "BOBİ FRS Bölüm 13:Yatırım Amaçlı Gayrimenkuller" standartlarında işletmenin kullanımı amacını taşıyan gayrimenkuller ile yatırım amaçlı gayrimenkuller farklı sınıflandırılmıştır (KGK, TFRS 2019 Seti; KGK, BOBİ FRS).Kira geliri ve/veya sermaye kazancı elde etmeamaçlı gayrimenkuller (arsave/veya binalar) "yatırım amaçlı gayrimenkul” olarak isimlendirilmiş, bu nitelikteki gayrimenkullerin sinıflandırılması, ölçülmesi ve finansal tablolarla ilişkilendirilmesi ilgili standartlarda açıklanmıştır. Yatırım amaçlı gayrimenkulleri kendileri inşa edecek veya geliştirecek işletmeler MSUGT'ne uygun muhasebeleştirmede maliyet unsurlarını bir bilanço hesabı olan "258 Yapılmakta Olan Yatırımlar" hesabında izlerken, Taslak’ta işletmelere aynı uygulamayı "249 Yapılmakta Olan Yatırım Amaçlı Gayrimenkul Yatırımları ve Verilen Avanslar" hesabında yürütme olanağı verilmektedir. Taslak'ta 70 grubunda sunulan seçenekte, dönem içinde inşası henüz tamamlanmamış yatırım amaçlı gayrimenkullerin maliyeti Şekil 9'da gösterildiği gibi, "708 Yapılmakta Olan Yatırım Amaçlı Gayrimenkuller Yatırım Maliyetleri" hesabında izlenebilir. Yatırım amaçlı gayrimenkul tamamlandığında varlığın maliyeti doğrudan ilgili (245, 246 veya 247 kodlu) varlık hesabına alınır. Bu yöntemi seçen işletmeler için "249 Yapılmakta Olan Yatırım Amaçlı Gayrimenkul Yatırımları ve Verilen Avanslar" hesabı yalnızca dönem sonunda "708 Yapılmakta Olan Yatırım Amaçı Gayrimenkuller Yatırım Maliyetleri” hesabının aktarılması amacıyla kullanilır.

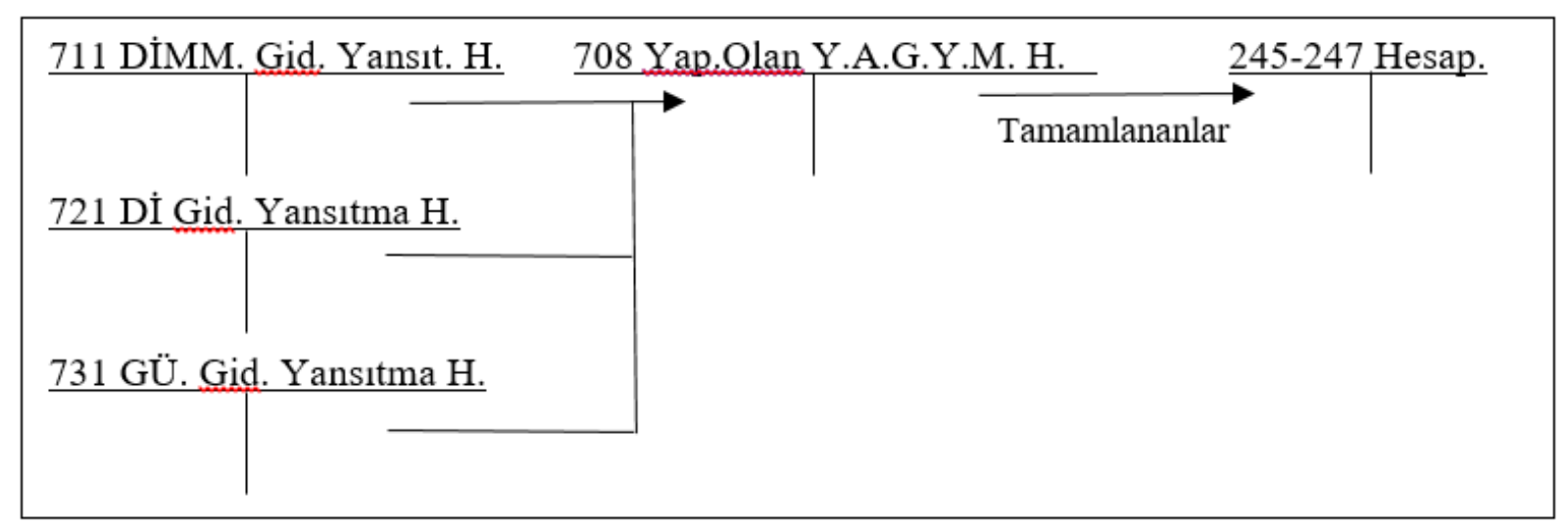

Şekil 9: 708 Yapılmakta Olan Yatırım Amaçlı Gayrimenkuller Yatırım Maliyetleri Hesabının Dönem İçi Kullanımı

\subsubsection{Direkt İlk Madde ve Malzeme Giderleri Grubunun Değerlendirilmesi}

“71 Direkt İlk Madde ve Malzeme Giderleri” grubu incelendiğinde hesap isimlerinde bir farklılık bulunmadığı, ancak hesap açıklamalarına Taslak'ta getirilen yeniliklere uygun olarak eklemelerde bulunulduğu, genel olarak hesapların kullanımına ilişkin açıklamaların genişletildiği gözlemlenmiştir. Söz konusu eklemeler aşağıdaki gibi sıralanabilir (KGK, 2018: 166-167):

$\checkmark \quad$ “710 Direkt İlk Madde ve Malzeme Giderleri” hesabının açıklamasına dönem sonunda yansıtma hesabıyla karşılaştırılarak kapatılması gerektiği açıklaması eklenmiştir. 
$\checkmark \quad$ Hizmet üretim işletmeleri isterlerse ürettikleri hizmetle doğrudan bağlantısı kurulabilen ilk madde ve malzeme giderlerini 74 grubunda değil, "710 Direkt İlk Madde ve Malzeme Giderleri” hesabında izleyebileceklerdir. Canlı varlık üretiminde kullanılacak ilk madde ve malzemeler de bu hesapta izlenecektir.

$\checkmark \quad 710$ kodlu hesapta dağıtım anahtarı gerektirmemesi şartıyla doğrudan mamulle ilişkilendirilebilen önemli tutardaki malzemeler, yardımcı malzemeler ve ambalaj malzemeleri de direkt ilk madde ve malzeme olarak muhasebeleştirilebilecektir.

$\checkmark \quad$ Eş zamanlı kayıt sistemi benimsenmekle birlikte gider yeri veya faaliyet merkezi kullanılması gerekliliği belirtilmiştir. Eşzamanlı kayıtta faaliyet merkezi kullanımı faaliyete dayalı maliyetleme kullanan işletmeler için öngörülmüştür.

$\checkmark \quad$ "711 Direkt İlk Madde ve Malzeme Giderleri Yansıtma" hesabının açıklaması,71 grubunu kullanmayı tercih eden hizmet işletmelerine ve 70 grubunu kullanmayı tercih eden işletmelere yönelik eklemeler yapılarak genişletilmiştir.

$\checkmark \quad 711$ kodlu hesabın açıklamasında fiili maliyet yöntemini uygulayan işletmelerde gerçekleşen anormal fire ve kayıplarda bu hesabın alacaklandırılarak “625 Stok Anormal Fire ve Kayıpları” hesabına aktarılması gerektiği belirtilmiştir.

$\checkmark \quad$ Önceden saptanmış maliyet yöntemlerini uygulayan işletmelerde ortaya çıkan direkt ilk madde ve malzeme ile ilgili fiyat ve miktar farklarınınhangi hesaplarda muhasebeleştirileceğine ilişkin açıklama yapılmıştır.

\subsubsection{Direkt İşçilik Giderleri Grubunun Değerlendirilmesi}

Hesap isimlerinde bir farklılı bulunmayan "72 Direkt İşçilik Giderleri” grubu incelendiğinde de hesap açıklamalarına eklemelerde bulunulduğu, hesapların kullanımına ilişkin açıklamaların genişletildiği gözlemlenmiştir. Söz konusu eklemeler aşağıdaki gibi siralanabilir (KGK, 2018: 168-169):

$\checkmark \quad$ Ürettikleri hizmetle doğrudan bağlantısı kurulabilen işçilik giderlerini 74 grubunda izlemek istemeyen hizmet işletmelerinin "720 Direkt İşçilik Giderleri”" hesabını kullanabilecekleri bu hesabın açıklamasında belirtilmiştir.

$\checkmark \quad 720$ kodlu hesabın açıklamasına dönem sonunda yansitma hesabiyla karşılaştırılarak kapatılacağı açıklaması eklenmiştir.

721 Direkt İşçilik Giderleri Yansıtma" hesabının açıklamasında bu grubu kullanmayı tercih eden hizmet işletmelerine ve 70 grubunu kullanmayı tercih eden işletmelere yönelik açıklamalar yapılmıştır.

$\checkmark \quad 721$ kodlu hesabın açıklamasında fiili maliyet yöntemini uygulayan işletmelerde gerçekleşen boşa geçen sürelere ilişkin tutarların bu hesabın alacaklandırılarak "625 Stok Anormal Fire ve Kayıpları" hesabına aktarılması gerektiği belirtilmiştir.

Önceden saptanmış maliyet yöntemlerini uygulayan işletmelerde ortaya çıkan ücret ve süre farklarının hangi hesaplarda muhasebeleştirilmesi gerektiğine ilişkin açıklama yapılmıştır.

\subsubsection{Genel Üretim Giderleri Grubunun Değerlendirilmesi}

“73 Genel Üretim Giderleri” grubunda var olan hesap açıklamalarının detaylandırılmasının yanı sıra gruba dört ayrı fark hesabı eklenmiştir. Eklenen hesaplar, 
normal maliyet yönteminin gerektirdiği; “736 Değişken Genel Üretim Giderleri Hesabı”, "737 Değişken Genel Üretim Giderleri Yansıtma Hesabı" "738 Sabit Genel Üretim Giderleri Hesabı” ve "739 Sabit Genel Üretim Giderleri Yansitma Hesabı”dır.

Diğer bir önemli bulgu da MSUGT'nde “730 Genel Üretim Giderleri” hesabı yalnızca mamul üretim maliyetinin oluşumu için kullanılabilirken, Taslak'ta bu hesabın hizmet üretim maliyetinin oluşumunda da kullanılabileceği yeniliğinin getirilmiş olmasıdır.

710 ve 720 kodlu hesapların açıklamalarına paralel olarak "730 Genel Üretim Giderleri” hesabının muhasebeleştirilmesinde eş zamanlı kayıt sisteminde (faaliyete dayalı maliyetleme yapan işletmelerde) faaliyet merkezi kodunun dikkate alınması gerekliliği belirtilmiştir. 730 kodlu hesabın kapsamına girecek gider çeşitleri tek tek sayılarak hesap ayrıntılı bir biçimde tanımlanmış ve isteyen hizmet işletmelerinin bu hesabı kullanabileceği belirtilmiştir.

Taslak’ta "731 Genel Üretim Giderleri Yansıtma" hesabı ile ilgili olarak aşağıdaki değişiklikler yapılmıştır (KGK, 2018: 169-173):

$\checkmark \quad$ Hesabın açıklaması, bu hesabı kullanmayı tercih eden hizmet işletmelerine ve 70 grubunu kullanmayı tercih eden işletmelere yönelik eklemeler yapılarak genişletilmiştir.

Normal maliyet yöntemini uygulayan işletmelerde üretime yüklenemeyen sabit genel üretim giderlerinin "624 Dağıtılmayan Sabit Genel Üretim Giderleri” hesabında muhasebeleştirilmesi gerektiği açıklanmıştır.

$\checkmark \quad$ Fiili maliyet yöntemini uygulayan işletmelerde boşa harcanan genel üretim gideri oluşması durumunda bu hesabın alacaklandırılarak "625 Stok Anormal Fire ve Kayıpları" hesabına aktarılması gerektiği belirtilmiştir.

$\checkmark \quad$ Önceden saptanmış maliyet yöntemlerini uygulayan işletmelerde ortaya çıkan bütçe, verimlilik ve kapasite farklarının hangi hesaplarda muhasebeleştirileceğine ilişkin açıklama yapılmıştır.

$\checkmark \quad$ Hesabın açıklamasına dönem sonunda bu hesabın fonksiyon hesabıyla karşılaştırılarak kapatılacağı açıklaması eklenmiştir.

73 grubundaki en önemli değişiklik, gruba "736 Değişken Genel Üretim Giderleri” ve "738 Sabit Genel Üretim Giderleri” hesapları ile bunlara ilişkin iki yansıtma hesabının eklenmesidir. Dolayısıyla söz konusu dört hesabın açıklama ve işleyişlerinin tamamı Taslağa özgü yeniliktir. 736 ve 738 kodlu hesaplar normal maliyet yöntemini uygulayan, değişkensabit genel üretim giderlerini yardımcı hesap olarak değil ana hesap bazında izlemek isteyen işletmelerde kullanılmak üzere eklenmiştir. Bu hesapları benimseyen işletmeler doğal olarak "730 Genel Üretim Giderleri” hesabını kullanmayacaklardır. Bu hesaplar bir fonksiyon hesabı gibi çalışmakta, maliyet dönemleri sonunda kendi yansıtma hesapları aracılığıyla ilgili hesaplara aktarılmakta ve dönem sonunda yansıtma hesapları ile karşılaştırılarak kapatılmaktadır. Yansıtma hesaplarının açıklamalarında da fonksiyon hesaplarının çalışma esaslarının benimsendiği görülmektedir. 


\subsubsection{Hizmet Üretim Maliyetleri Grubunun Değerlendirilmesi}

74 Hizmet Üretim Maliyetleri grubu eskiden beri yıllara yaygın inşaat (taahhüt) işi yapan işletmelerde de kullanıldığı halde MSUGT'nde gruba ilişkin açıklamalarda bu işletmelerin ismine yer verilmemişti. Taslak'ta bu grubu kullanabilecek işletmeler açıklanırken hizmet işletmeleri denilmekle birlikte yıllara yaygın inşaat (taahhüt) işi yapan işletme ifadesi de açıkça belirtilmiştir. Grubun kullanımı MSUGT'nde hizmet işletmeleri için bir zorunluluk iken Taslak'ta bir tercih haline dönüşmüştür. Bu grupta en dikkat çekici farklılık "741 Hizmet Üretim Maliyetleri Yansıtma” hesabının açıklamasına geniş bir biçimde yer verilmesidir. Açıklama 711, 721, 731 kodlu hesaplara uygun bir biçimde düzenlenmiştir.

Diğer bir önemli ekleme de fark hesapları ile ilgilidir. Taslakta işletmelerin "742 Hizmet Üretim Maliyeti Fark" hesabının; gider çeşitleri farkları, direkt ilk madde ve malzeme maliyetleri farkları, direkt işçilik maliyetleri farkları, genel üretim maliyeti farkları gibi alt hesaplar açılarak da izlenebileceği açıklamalarda yer almıştır.Ayrıca 742 kodlu hesabın dönem sonunda ilgili stok hesabına ve 62 Satışların Maliyeti grubundaki ilgili hesaba aktarılacağı bilgisi de eklenmiştir.

\subsubsection{Araştırma, Geliştirme ve Maden Kaynaklarının Aranması ve Değerlendirilmesi Giderleri Grubunun Değerlendirilmesi}

Önemli bir farklılık da "75 Araştırma, Geliştirme ve Maden Kaynaklarının Aranması ve Değerlendirilmesi Giderleri" grubunda vardır. MSUGT'nde yer alan araştırma ve geliştirme gideri kavramı, "TMS 38: Maddi Olmayan Duran Varlıklar" ve "BOBİ FRS Bölüm 14: Maddi Olmayan Duran Varlıklar" standartlarının özüne uygun olarak "Araştırma Gideri” ve "Geliştirme Giderleri” olarak ayrılmıştır. Söz konusu standartlara göre araştırma harcamaları aktifleştirilmeden gider olarak muhasebeleştirilirken, geliştirmeden kaynaklanan harcamalar standartta belirtilen koşulları taşımaları halinde aktifleştirilebilir (KGK, TFRS 2019 Seti; KGK, BOBİ FRS).

Muhasebeleştirme açısından araştırma ve geliştirme kavramlarına getirilen bu farklılık, ilk üç hesabın isimlerinin MSUGT'nde yer alan isimlerden farklı olarak; "750 Araştırma Giderleri”, "751 Araştırma Giderleri Yansıtma" ve "752 Araştırma Gider Farkları" hesabı şeklinde ifade edilmesine sebep olmuştur. Bu gruptaki önemli farklılık yeni hesaplar eklenmesidir. Eklenen hesaplar aşağıdaki gibidir:

753 Geliştirme Giderleri Hesab1

754 Geliştirme Giderleri Yansıtma Hesabı

755 Geliştirme Gider Farkları Hesabı

756 Maden Kaynaklarının Aranması ve Değerlendirilmesi Giderleri Hesabı

757 Maden Kaynaklarının Aranması ve Değerlendirilmesi Giderleri Yansıtma Hesabı

758 Maden Kaynaklarının Aranması ve Değerlendirilmesi Giderleri Farkları Hesabı 
Taslak’ta “750 Araştırma Giderleri” hesabının açıklaması MSUGT’ne göre dar tutulurken, "751 Araştırma Giderleri Yansıtma" hesabının açıklaması genişletilmiştir. 751kodlu hesaba yansitılan araştırma giderlerinin dönem sonunda aktifleştirilmeden, bir kar zarar tablosu hesabı olan "630 Araştırma ve Geliştirme Giderleri” hesabına aktarılacağı; önceden saptanmış maliyet yöntemleri kullanan işletmelerde oluşan farkların fark hesabına aktarılacağı açıklamaları eklenmiştir. 751 kodlu hesabın açıklamasına yapılan geniş çaplı bir ekleme de, maddi olmayan duran varlık yatırımlarını "70 Maliyet Oluşum” grubu içerisinde izlemeyi tercih eden işletmeleri ilgilendirmektedir. $\mathrm{Bu}$ işletmeler için 751 hesab1 alacaklandırarak araştırma tutarlarının "707 Yapılmakta Olan Maddi Olmayan Duran Varlık Yatırım Maliyetleri” hesabına aktarılacağı açıklaması eklenmiştir."752 Araştırma Gider Farkları" hesabındaki farklılık yalnızca hesap ismi bazındadır.

Taslakta geliştirme giderleri ile ilgili yeni hesaplar açılmış ve açıklamaları eklenmiştir. "753 Geliştirme Giderleri” hesabı hem maden işletmelerinin geliştirme faaliyetlerine hem de diğer işletmelerin geliştirme faaliyetlerine ilişkin giderlerini muhasebeleştirmek amaciyla planlanmıştır. 753 hesabın açıklamasında açıkça ifade edilmeyen bu amaç hesabın işleyişinde "757 Maden Kaynaklarının Aranması ve Değerlendirilmesi Giderleri Yansıtma” hesabı ile kurulan bağlantıdan anlaşılmaktadır.

“754 Geliştirme Giderleri Yansıtma” hesabı geliştirme amacıyla yapılan giderlerin ilgili hesaplara aktarılması amacıyla kullanılan bir hesaptır. Önceden saptanmış maliyet yöntemleri kullanan işletmelerde oluşan geliştirme hesabı ile ilgili farkların muhasebeleştirilmesi amacıyla "755 Geliştirme Gider Farkları” hesabı açılmıştır.

$\mathrm{Bu}$ gruba maden kaynaklarının aranması/araştırılması ile ilgili faaliyet gösteren işletmeler için üç hesap eklenmiştir. Maden kaynaklarını işleten işletmelerde üretim öncesi faaliyetler maden kaynaklarının aranması, araştırılması, değerlendirilmesi ve geliştirilmesi aşamalarında gerçekleştirilmektedir (Özbek, 1996: 26). Bu aşamaların her birisi maliyetlerin oluştuğu faaliyetlerdir. Taslak’ta arama, araştırma ve değerlendirme faaliyetleri nedeniyle oluşan maliyetler "756 Maden Kaynaklarının Aranması ve Değerlendirilmesi Giderleri" hesabında borçlandırılırken, başarısız sonuçlar "757 Maden Kaynaklarının Aranması ve Değerlendirilmesi Giderleri Yansıtma" hesabının alacağı aracılığıyla "630 Araştırma ve Geliştirme Giderleri” hesabına, başarılı sonuçlar ise aynı yansıtma hesabının alacağı aracılığıyla ilgili varlık hesabına aktarılır. Önceden saptanmış maliyet yöntemleri kullanan işletmelerde oluşan farkların muhasebeleştirilmesi amacıyla "758 Maden Kaynaklarının Aranması ve Değerlendirilmesi Giderleri Farkları" hesabı açılmıştır. Farklar 757 kodlu yansıtma hesabının alacağı aracılığıyla, farkın olumlu/olumsuz olma durumuna göre 758 kodlu fark hesabının borç veya alacağına kaydedilir. Bu fark hesabı da dönem sonunda diğer maliyet hesapları gibi kapatılır.

\subsubsection{Pazarlama, Satış ve Dağıtım Giderleri ile 77 Genel Yönetim Giderleri Gruplarının Değerlendirilmesi}

“76 Pazarlama, Satış ve Dağıtım Giderleri” ile "77 Genel Yönetim Giderleri” gruplarında önemli farklılıklara rastlanmamıştır. Her iki grupta da fonksiyon hesaplarına "işleyişi” başlığı eklenerek hesapların işleyiş̧ine ilişkin açıklamalar genişletilmiştir. Her iki grup için ortak olarak söylenebilecek bir diğer farklılık da yansıtma hesapları konusundadır. Yansıtma hesaplarına önceden saptanmış maliyet yöntemleri kullanan işletmeler için ortaya 
çıkabilecek farkların fark hesaplarına aktarılması gerektiğine ilişkin açıklama eklenmiştir. Fark hesaplarında herhangi bir farklılık gözlenmemiştir.

77 Genel Yönetim Giderleri grubunun kapsamı açıklanırken "yönetim fonksiyonuyla ilgili giderler" ifadesinin yanına "genel işletme giderleri”" ifadesi de eklenmiştir.

\subsubsection{Finansman Giderleri Grubunun Değerlendirilmesi}

"78 Finansman Giderleri” grubunun giriş kısmında işletmenin borçlanma kaynakları ve borçlanma maliyetini oluşturan unsurlar tek tek sayılarak grubun açıklama kısmı detaylandırılmıştır. Muhasebe standartlarının gereği olarak hesaplanan vade farklarının bu grubu ilgilendirmediği özellikle vurgulanmıştır.

“780 Finansman Giderleri” hesabının açıklama kısmı genişletilerek MSUGT’nde olmayan hesabın işleyişi kısmı eklenmiş, ayrıca dönem sonlarında hesabın yansıtma hesabıyla karşılaştırılarak kapatılması gerekliliği açıklanmıştır.

“781 Finansman Giderleri Yansıtma” hesabının açıklama kısmı genişletilirken, aktarma yapılacak hesaplara "TMS 23: Borçlanma Maliyetleri”ve "BOBİ FRS Bölüm 17: Borçlanma Maliyetleri” standartları (KGK, TFRS 2019 Seti; KGK, BOBİ FRS) gereğince, aktarılması mümkün olan varlık hesabına aktarılabilme seçeneği de eklenmiştir. Ayrıca olası farkların "782 Finansman Giderleri Fark" hesabına yansıtılabileceği açıklaması da Taslak'ta yer almıştır. Dönem sonunda fark hesabının ilgili kâr zarar tablosu hesapları ile uygunsa ilgili varlık hesabına aktarılarak kapatılabileceği de açıklanmıştır.

\subsubsection{Gider Çeşitleri ve Gider Yerlerinin Değerlendirilmesi}

Taslak'ta gider çeşitleri başlığında yer alan gider çeşitleri MSUGT'ndekilerle bire bir aynı olmakla birlikte, "ilk madde ve malzeme giderleri" ile "finansman giderleri”"ne ilişkin açıklamalar genişletilmiştir.7/B seçeneğini kullanabilecek işletmeler için kurgulanan "79 Gider Çeşitleri" grubundaki hesap isimleri ile hesapların açıklama ve işleyişlerinde MSUGT'ne göre bir farklılık dikkati çekmemiştir.

“Sorumluluk merkezi” kavramı Taslak’ta "Gider Yerleri” başlığının yanında parantez içerisinde geçmiştir. Ayrıca tüm Taslak boyunca ilgili kısımlarda faaliyete dayalı maliyetleme yapan işletmeler için "faaliyet merkezi” kavramına yer verilmiştir.İlk kez 1986 yılında mamul maliyetinin hesaplanması için farklı bir yaklaşım olarak geliştirilen (Yılmaz, 2004: 30) faaliyete dayalı maliyetlemeyönteminin 1994 yılında uygulamaya giren MSUGT'nde yer bulamadığı bilinmektedir.

\section{SONUÇ}

Muhasebede yaşanan güncel gelişmeler sonucunda sektörlerin ve akademik çevrelerin ihtiyaç duyduğu, muhasebe standartlarına uygun hesap planı taslağı KGK tarafında 2018 yılının sonunda ilgililerin görüşüne açılmıştır. Çalışmamız Taslak'ta yer alan maliyet hesapları sınıfının 1994 yılından bu yana uygulanmakta olan MSUGT'ndeki maliyet hesapları sınıfı ile karşılaştırmalı bir analizinin yapılarak benzer ve farklı yönlerinin ortaya konulmasını amaçlamaktadır. Analizin yapılabilmesi için nitel araştırma yöntemi kullanılmıştır. Çalışma 
sonucunda; maliyet, harcama, gider kavramlarındaki karmaşanın devam ettiği, her iki hesap planında da hesap sınıfı bazında maliyet hesaplarına yönelik temel uygulamaların aynı olduğu gözlemlenmiştir. İki hesap planı arasında maliyet hesapları sınıfında hesap gruplarının ismi açısından iki grupta farklılığa rastlanırken, bazı hesap gruplarının içeriğinde önemli farklılıklar olduğu gözlemlenmiştir. İçerik açısından farklılık olan gruplarda hesap sayısında artış olduğu ifade edilmelidir. Taslak'ta hesap açıklamalarının zenginleştirildiği, önceki hesap planında eksik olan veya hiç olmayan açıklamaların eklendiği de dikkat çekmektedir.

MSUGT ve Taslak'ta işletmelerin büyüklügüne bağlı olarak uygulanan 7/A ve 7/B seçenekleri korunmuştur. 70 gurubu her iki hesap planında da aynı amaca hizmet etmekle birlikte, Taslak'ta bu gruba farklı bir işlev daha yüklenerek isteyen işletmelere bu grup aracılığıyla farklı uygulamalar yapma olanağı sağlanmıştır.

Hesap gruplarının içeriği açısından yapılan incelemede 70,73 ve 75 gruplarında standartların doğasına uygun önemli değişikler yapıldığı, yeni hesaplar açıldığı görülmektedir. 70 grubuna eklenen hesapların kullanımı ihtiyaridir. Standartlarda yer alan normal maliyet yönteminin gereği olarak, giderlerini sabit-değişken gider ayrımı yaparak izleyecek işletmeler için bu giderleri muhasebeleştirebilecekleri fonksiyon ve yansitma hesapları 73 grubunun altında tanımlanmıştır.

75 grubunda standartların doğasına uygun olarak araştırma giderleri ile geliştirme giderlerinin muhasebeleştirilmesi konusunda önemli değişiklikler getirilmiştir. Ayrıca bu grup maden kaynaklarının araştırılması ve değerlendirilmesi ile ilgili işletmelerin kullanabileceği bir grup haline getirilmiştir.

Taslak'ta yer alan önemli bir yenilik de hizmet üretiminde yalnızca 74 grubu hesapların kullanılma zorunluluğunun olmamasıdır. İsteyen işletmeler mamul üreten işletmelerin kullandığı fonksiyon hesaplarını da kullanabilecektir. Bu da hizmet üretim maliyetlerinin daha ayrıntılı izlenmesi olanağını sağlamaktadır. MSUGT'ni uygulayan bazı hizmet işletmelerinin bu ihtiyacı "740 Hizmet Üretim Maliyeti" hesabının yardımcı hesaplarını kullanarak giderdiği bilinmektedir.

Hesapların içerikleri incelendiğinde "720 Direkt İşçilik Giderleri”, "730 Genel Üretim Giderleri”, "740 Hizmet Üretim Maliyeti”, "760 Pazarlama Satış ve Dağıtım Giderleri”, "770 Genel Yönetim Giderleri” ve "780 Finansman Giderleri” hesaplarına "hesabın işleyişiı" başlıkları eklenmiştir. Ayrıca genel olarak hesap açıklamalarının daha ayrıntılandırıldığı sonucuna ulaşılmıştır. Olumlu olarak değerlendirilen bu gelişme, hesapların işleyişi konusundaki tereddütleri azaltacak ve uygulama birliği konusunda katkı sağlayacaktır.

Gider çeşitleri ve gider yerleri açısından önemli bir değişiklik gözlemlenmemiştir. Taslak'ta faaliyete dayalı maliyet kullanan işletmeler dikkate alınmış, bu işletmelerin eş zamanlı kayıtta gider yeri yerine faaliyet merkezi kullanabilecekleri belirtilmiştir.

Taslak KGK tarafından belirli bir süre konularak kamuoyu ile paylaşılmış ve görüşler alınmıştır. Bunda amaç hesap planının olgunlaştırılarak yayımlanmasıdır. Henüz taslak halindeki hesap planı konusunda yapılacak gerek başı ıaşına gerekse karşılaştırmalı çalışmaların da, hesap planının olabildiğince olgunlaşmış bir biçimde yayımlanmasına, dolayısıyla uygulamacılara daha yararlı olacağı kanaatindeyiz. 


\section{KAYNAKÇA}

Akdoğan, Nalan- Sevilengül, Orhan (2007), “Türkiye Muhasebe Standartlarına Uyum İçin Tekdüzen Hesap Planında Yapılması Gereken Değişiklikler”, Mali Çözüm,S.84, Kasım-Aralık, ss. 29-70, archive.ismmmo.org.tr/docs/malicozum/84malicozum/02\%20nalanakdogan.pdf (Erişim Tarihi: 03.01.2019)

Altıntaş, A.Taylan (2011),“Uluslararası Muhasebe ve Türkiye'de Muhasebe Hukuku”, Sosyal Bilimler Dergisi,S.1, ss. 162-174, dergipark.gov.tr/download/article-file/100755 (Erişim Tarihi: 10.01.2019)

Bayri, Osman (2010), “Tekdüzen Muhasebe Sistemine ve Türkiye Muhasebe-Finansal Raporlama Standartlarına Göre Bilançonun Biçimsel Yapısı, Kapsamı ve İçeriğinin Karşılaştırmalı Analizi”, Mali Çözüm, 98, ss.89-116.

Dinç, Engin - Atabay, Esra (2019), "Tekdüzen Muhasebe Sisteminde Gerçekliği Bozan Hükümler Ve Güncelleme İhtiyacı", Uluslararası İktisadi Ve İdari İncelemeler Dergisi, 22, 179-192. Https://Dergipark.Org.Tr/Download/Article-File/605547 (Erişim Tarihi: 10.03.2019)

Doğan, Aziz (2018), "Büyük Ve Orta Boy İşletmeler İçin Finansal Raporlama Standardı İle VUK/MSGUT Karşılaştırması”, Muhasebe Ve Finansman Dergisi, S.80, ss.115-132, Dergipark.Gov.Tr/Download/Article-File/545689 (Erişim Tarihi: 15.12.2018)

Duverger, Maurice (1973), Metodoloji Açısından Sosyal Bilimlere Giriş, Çev. Ünsal Oskay, Ankara: Bilgi Yayınevi.

Gökçen, Gürbüz - Ataman Başak - Çakıcı, Cemal (2016), Türkiye Finansal Raporlama Standartları Uygulamaları, 2.B., İstanbul: Beta Yayınları.

Gökçen, Gürbüz - Öztürk, Erkan (2017), “Tam Ve Normal Maliyet Yöntemlerinin UFRS (TFRS) Ve BOBİ FRS'deki Düzenlemeler Çerçevesinde İncelenmesi”, Finans, Ekonomi Ve Sosyal Araştırmalar Dergisi, 2(2), ss.105-114. https://Dergipark.Org.Tr/Download/Article-File/354101 (Erişim Tarihi: 16.12.2018)

Kamu Gözetimi Muhasebe ve Denetim Standartları Kurumu (2018), Finansal Raporlama Standartlarına Uygun Hesap Planı Taslağ1. http://www.kgk.gov.tr/Portalv2Uploads/files/Duyurular/v2/TFRS/EK2_Finansal\%20R aporlama\%20Standartlar\%C4\%B1na\%20Uygun\%20Hesap\%20Plan\%C $4 \%$ B1\%20Tas la\%C4\%9F\%C4\%B1.pdf (Erişim Tarihi: 02.02.2019)

Kamu Gözetimi Muhasebe ve Denetim Standartları Kurumu, Türkiye Finansal Raporlama Standartları (TFRS), http://www.kgk.gov.tr/DynamicContentDetail/9182/TMS/TFRS2019-Seti, (Erişim Tarihi: 17.02.2019) 
Kamu Gözetimi Muhasebe ve Denetim Standartları Kurumu, Büyük ve Orta Boy İşletmeler İçin Finansal Raporlama Standardı (BOBİ http://www.kgk.gov.tr/Portalv2Uploads/files/PDF\%20 linkleri/bobi_frs.PDF, (Erişim Tarihi: 17.02.2019)

Koç, Yüksel (1972), “Tekdüzen Muhasebe Sistemi”, Ankara Üniversitesi SBF Dergisi, 27(3), ss.971-990.

Özbek, Cevdet Yiğit (1996), Maden İşletmelerinde Üretim Öncesi Faaliyetlerden Kaynaklanan Maliyetlerin Muhasebeleştirilmesi, (Yayımlanmamış Doktora Tezi), Ankara: Gazi Üniversitesi Sosyal Bilimler Enstitüsü.

Özkan, Mehmet- Terzi, Serkan (2012), "Finansal Raporlama Açısından Marka Değerinin Ölçümü ve Değerlendirilmesi”, Öneri, C. 10, S. 38, Temmuz, ss. 87-96, dergipark.gov.tr/download/article-file/165713 (Erişim Tarihi: 18.02.2019)

Özulucan, Abitter- Deran, Ali (2008). "41 Nolu Türkiye Muhasebe Standardı (TMS 41), Vergi Usul Kanunu ve Tekdüzen Hesap Planı Açısından Küçük ve Büyükbaş Canlı Varlıkların Muhasebeleştirilmesi ve Değerleme İşleminde Karşılaşılan Güçlükler ve Çözüm Önerileri”, Erciyes Üniversitesi Sosyal Bilimler Enstitüsü Dergisi, (1)25, ss.123.

Sermaye Piyasası Kurulu (SPK) (1984), Seri VIII No: 7 Standart Hesap Planı ve Planın Kullanım Esasları Tebliği (Resmi Gazete, 1 Şubat 1984 tarih 18299 sayı, ss.5-35.

TÜRMOB, Muhasebenin Temel Kavramları ve Tekdüzen Hesap Planı, TÜRMOB Yayınları, Ankara.

Yılmaz, Bülent (2004), Muhasebe Eğitiminde Faaliyete Dayalı Maliyetlendirme ve Bir Örnek Uygulama, (Yayımlanmamış Yüksek Lisans Tezi), Ankara: Gazi Üniversitesi Eğitim Bilimleri Enstitüsü. 